\title{
In vitro antifungal activity of Myracrodruon urundeuva Allemão against human vaginal Candida species
}

\author{
FERNANDO A. DE OLIVEIRA ${ }^{1}$, VANESSA C. RORATO ${ }^{2}$, ADRIANA A. ALMEIDA-APOLONIO ${ }^{3}$, \\ ALLAN B. RODRIGUES ${ }^{1}$, ALINE L. DE BARROS ${ }^{2}$, ANDRÉIA SANGALLI ${ }^{2}$, ARIELLE C. \\ ARENA $^{4}$, JONAS S. MOTA ${ }^{5}$, ALEXÉIA B. GRISOLIA ${ }^{6}$ and KELLY M.P. DE OLIVEIRA ${ }^{6}$
}

\author{
${ }^{1}$ Faculdade de Ciências Exatas e Tecnologia, Universidade Federal da Grande Dourados, Rodovia \\ Dourados - Itahum, Km 12, Cidade Universitária, 79804-970 Dourados, MS, Brazil \\ ${ }^{2}$ Faculdade de Ciências da Saúde, Universidade Federal da Grande Dourados, Rodovia Dourados \\ - Itahum, Km 12, Cidade Universitária, 79804-970 Dourados, MS, Brazil \\ ${ }^{3}$ Faculdade de Medicina, Universidade Federal de Mato Grosso do Sul, Av. Costa e \\ Silva, s/n, Cidade Universitária, 79070-900 Campo Grande, MS, Brazi \\ ${ }^{4}$ Departamento de Morfologia, Universidade Estadual Paulista "Júlio de Mesquita Filho", \\ R. Luís Cassineli, Jardim São Jose, 18618-024 Botucatu, SP, Brazil \\ ${ }^{5}$ Departamento de Química, Universidade Estadual de Mato Grosso do Sul, Rodovia Dourados \\ - Itahum, Km 12, Cidade Universitária, 79804-970 Dourados, MS, Brazil \\ ${ }^{6}$ Faculdade de Ciências Biológicas e Ambientais, Universidade Federal da Grande Dourados, Rodovia \\ Dourados - Itahum, Km 12, Cidade Universitária, 79804-970 Dourados, MS, Brazil
}

Manuscript received on April 3, 2017; accepted for publication on May 4, 2017

\begin{abstract}
Myracrodruon urundeuva is a plant native to Brazil, which is used by the indigenous population for the treatment of candidiasis. The aims of this study were to evaluate the antifungal activity of extract against human vaginal Candida species and evaluate the possible toxicological activities of M. urundeuva. Initially, ethanol extracts, ethyl acetate fractions, and hydroalcoholic fractions of the bark and leaf of M. urundeuva were used to determine the minimum inhibitory concentration. The extracts that showed antifungal activity were characterized by liquid chromatography and subjected to toxicity assessment. Toxic, cytotoxic, genotoxic, and mutagenic testing were performed using Allium cepa and Ames assays with the ethanol extracts of the bark and leaves. Hemolytic activity was evaluated in erythrocytes and acute toxicity in rats. The ethanol bark extracts showed best activity against Candida albicans, C. krusei, and C. tropicalis ATCC $(4-512 \mu \mathrm{g} / \mathrm{mL})$. Chemical characterization indicated the presence of flavonoids and tannins in the extracts. Hemolytic activity, genotoxicity, and mutagenicity were not observed. The results of the Ames and A. cepa tests were also in agreement, ethanol bark extracts and ethanol leaf extracts of M. urundeuva showed absence of mutagenic activity. Similar results were observed in the A. cepa assay and acute toxicity test in rats. M. urundeuva bark extracts showed potential for the treatment of vaginal infections caused Candida species, as a topical.
\end{abstract}

Key words: Anacardiaceae, candidiasis, Myracrodruon urundeuva, traditional medicine.

Correspondence to: Kelly Mari Pires de Oliveira

E-mail: kmpoliveira@hotmail.com 


\section{INTRODUCTION}

Vulvovaginal candidiasis is a common fungal infection among women causes physical and psychological discomfort relevant in women's health. The infection is caused by opportunistic Candida yeasts that are commensal vaginal mucosa (Álvares et al. 2007). C. albicans is responsible for over $90 \%$ of cases of infection vulvovaginal (Ilkit and Guzel 2011). Normally, due to the characteristic symptoms of infection, women perform selfdiagnosis and seek treatment alternatives as sitz bath with natural products.

Myracrodruon urundeuva Allemão (Anacardiaceae) is popularly known as aroeira, and can be found in Brazil (northeast, southeast, and mid-west regions), Bolivia, Paraguay, and Argentina (Lorenzi and Matos 2008). It the bark infusion is used by the indigenous population of Brazil for the treatment of vaginal infections. According to reports of the indigenous women of the village Jaguapiru, the infusion of the bark as sitz bath promotes symptom relief (Lopes 2011). Studies have reported that extracts of this plant have an antifungal activity (Jandú et al. 2013).

The study of toxicity, genotoxicity and mutagenicity of plants popularly used in traditional medicine are important to avoid adverse reaction. Several studies have focused on the discovery of new derived bioactive agents from vegetable extracts and other natural products that have demonstrated effectiveness in the treatment of diseases and limited toxicity (Bagiu et al. 2012, Eren and Özata 2014, Gehrke et al. 2013). Toxicological evaluation with several different methodologies is recommended to ensure accurate results (Brasil 2015, WHO 2005). The tests that have been used for evaluation are: Ames test (Maron and Ames 1983), Allium cepa test (Fiskesjö 1994), hemolytic activity assessment (Khalil and El-Adawy 1994) and acute toxicity tests in rats (OECD 2015).
The World Health Organization (WHO 2005) estimates that the plant extracts or their active ingredients are used in folk medicine in traditional therapies $80 \%$ of the world population. The evaluation of the effectiveness of antimicrobial action and possible toxicity are relevant for proper and safe therapy. In this sense, the aims of the study were to evaluate the antifungal activity of extract against yeast from vaginal secretions from women and evaluate the possible toxicological activities of M. urundeuva.

\section{MATERIALS AND METHODS}

\section{PLANT MATERIAL}

The bark and leaves of $M$. urundeuva were collected in a farm of the Universidade Federal da Grande Dourados (UFGD), Dourados - Mato Grosso do Sul, Brazil (S 22¹4" 877 W 54' 59" $615)$. The voucher specimen was identified by Dr. Zefa Valdivina Pereira and deposited in the herbarium of the Faculdade de Ciências Biológicas e Ambientais, Universidade Federal da Grande Dourados, under registration number 534.

\section{PREPARATION OF EXTRACTS}

Dried plant materials $(100 \mathrm{~g})$ were extracted with $900 \mathrm{~mL}$ of absolute ethanol for $48 \mathrm{~h}$ at $25^{\circ} \mathrm{C}$, with occasional agitation. After filtration, the ethanol extract was evaporated at $35^{\circ} \mathrm{C}$ on a rotary evaporator and lyophilized. The crude extract was partitioned with ethyl acetate and chloroform, based on increasing polarity of the solvent. Extraction using different solvents is based on the chemical properties of each, in this case according to their polarity. This causes each substance present in the plant to interact differently with each solvent, which makes it possible to extract the compounds according to their polarity, in different fractions. The ethanol extracts, hydroalcoholic fractions, and ethyl acetate fractions of the bark and leaves of 
M. urundeuva were dried and stored at $4{ }^{\circ} \mathrm{C}$ until analysis.

\section{ANALYSIS OF THE EXTRACTS BY HIGH- PERFORMANCE LIQUID CHROMATOGRAPHY (HPLC)}

The ethanol extracts of the bark and leaves were analyzed by HPLC (VARIAN 210), with a diode array detector (DAD), scanning between 200-800 $\mathrm{nm}$. The chromatographic column used was a Phenomenex C18 column (Ø $4.6 \mathrm{~mm} \times \| 250 \mathrm{~mm}$, particle diameter $10 \mu \mathrm{m})$ and a guard column $(25$ $\mathrm{mm} \times 3 \mathrm{~mm}$ ) of the same phase was used. Elution of solvents was performed by the gradient method: $\mathrm{MeOH} / \mathrm{H}_{2} \mathrm{O} 5$ to $100 \%$ methanol, taking $15 \mathrm{~min}$ to reach $100 \%$ methanol, $100 \%$ methanol for $5 \mathrm{~min}, 5$ $\mathrm{min}$ to return to the initial condition, $25 \mathrm{~min}$ in total, with flow rate of $1 \mathrm{~mL} / \mathrm{min}$, and injection volume of $5 \mu \mathrm{L}$. Prior to injection, the samples were filtered through a $0.45 \mu \mathrm{m}$ microfilter.

\section{ANTIFUNGAL ACTIVITY ASSAYS}

\section{Microorganisms}

We used 15 yeast isolates from vaginal secretions from women and American Type Culture Collection (ATCC, Rockville, MD, USA) strains Candida albicans 90028, C. krusei 6258, C. tropicalis 750, and C. glabrata 2001. Microorganisms are part of yeast bank Applied Microbiology Laboratory / UFGD.

\section{Determination of the minimum inhibitory concentration (MIC) of the extracts}

The MIC was determined by the microdilution broth technique, with some adaptations for natural products (CLSI 2008). The ethanol extracts, ethyl acetate fractions, and hydroalcoholic fractions of the bark and leaves were dissolved in dimethyl sulfoxide (DMSO, Sigma-Aldrich $\AA$, St. Louis, MO, USA), and serial diluted (1:2) in sterile microplates to obtain concentrations of 0.004 ,
$0.008,0.016,0.032,0.064,0.128,0.256,0.512$, 1.024 and $2.048 \mathrm{mg} / \mathrm{mL}$. The suspension of each microorganism tested was at concentration of 0.5 McFarland, resulting in $0.5 \times 10^{3}$ to $2,5 \times 10^{3} \mathrm{CFU} /$ $\mathrm{mL}$. RPMI-1640 (Sigma-Aldrich ${ }^{\circledR}$ ) for yeast was used as the culture medium. The microplates were incubated for $48 \mathrm{~h}$ at $37^{\circ} \mathrm{C}$. The MIC was defined as the lowest concentration that inhibited fungal growth. The test was performed in triplicate at two different occasions.

\section{Minimum fungicide concentration (MFC)}

Aliquots from each well of the microplate were transferred with sterile toothpicks to a Petri plate containing Sabouraud dextrose agar. Plates were incubated for $48 \mathrm{~h}$ at $37^{\circ} \mathrm{C}$. The MFC were defined as the lowest concentration that did not show fungal growth (Bagiu et al. 2012).

\section{Allium cepa TEST}

The concentrations of the extracts (bark and leaves) were $0.2 ; 0.3 ; 0.4 ; 0.5$, and $1 \mathrm{mg} / \mathrm{mL}$. Each concentration was prepared in three plates $(100 \times 15 \mathrm{~mm})$. One hundred A. cepa (Isla ${ }^{\circledR}$, Porto Alegre, RS, BR) seeds were distributed on each plate that contained filter paper moistened with 3 $\mathrm{mL}$ of ethanol extracts of the bark or leaves of $M$. urundeuva. Distilled water was used as the negative control and trifluralin (Nortox ${ }^{\circledR}$, Arapongas, PR, BR) $(84 \mathrm{mg} / \mathrm{mL})$ and $3 \%$ formalin were employed as the positive control (Fernandes et al. 2007).

The roots of the germinated seeds were measured using a millimeter ruler over five days to calculate the germination index (GI) and evaluate toxicity. On the fifth day, the roots were collected, pre-treated, and fixed in Carnoy solution (acetic acid and ethanol in the ratio of $3: 1, v / v$ ) for $24 \mathrm{~h}$. Subsequently, they were washed three times with distilled water, hydrolyzed in $\mathrm{HCl}(5 \mathrm{M})$ for 10 min in a water bath at $60{ }^{\circ} \mathrm{C}$, then washed again, and stained with Schiff reagent for $45 \mathrm{~min}$ (in the 
absence of light). After, a section of the root apical meristem was obtained, placed on a slide, and 1 drop of acetic carmine (45\%) was added. This was covered with a cover slip and the slide was observed under a light microscope $(100 \times$ immersion $)$. One thousand cells were analyzed per slide under a microscope and five slides of each treatment were evaluated, with a total of five thousand cells analyzed per treatment.

Toxicity, cytotoxicity, genotoxicity, and mutagenicity

Germination index (GI) of the seeds and mediumsized (MS) roots were analyzed to assess toxicity. The chromosomal abnormalities index (CAI) and mutagenicity index (MtI) were used to evaluate genotoxicity and mutagenicity, respectively (Fernandes et al. 2007).

Germination index was determined by the equation: $\mathrm{GI}=\mathrm{NG} / \mathrm{TS} \times 100$, where $\mathrm{NG}=$ number of seeds that germinated and TS $=$ total exposed seed treatment. The average size of the roots was determined by measurements over the five treatment days.

Mitotic index (MI) was determined by the following equation: $\mathrm{MI}=\mathrm{NCM} / \mathrm{TC} \times 100$, where $\mathrm{NCM}=$ number of cells in mitosis and $\mathrm{TC}=$ total number of cells analyzed. We analyzed 1000 cells per slide under light microscope $(100 \times)$ and evaluated five slides of each treatment, with a total of 5000 cells analyzed per treatment.

The rate of chromosomal abnormalities (loss of chromosomes, c-metaphase, chromosome bridge, polyploidy, and multipolarity) was established by the following equation: $\mathrm{CAI}=\mathrm{NCA} / \mathrm{TC} \times 100$, where $\mathrm{NCA}=$ number of altered cells and $\mathrm{TC}=$ total observed cells. The mutagenicity index (MtI) was determined according to the following equation: $\mathrm{MtI}=\mathrm{NCMn}+\mathrm{NCB} / \mathrm{TC} \times 100$, where $\mathrm{NCMn}=$ number of cells that had micronuclei, $\mathrm{NCB}=$ number of cells that showed chromosomal break, and TC $=$ total number of observed cells. As with MI assessment, 1000 cells per treatment were analyzed, with five slides for each treatment.

\section{AMES TEST}

The test was conducted according to the preincubation method developed by Maron and Ames (1983). Toxicity is indicated by a reduction in the number of his + revertants or as background growth plates in minimal glucose agar (Mortelmans and Zeiger 2000). The Salmonella Typhimurium strains used were TA97a, TA98, TA100, and TA102.

The concentrations of ethanol bark extracts and ethanol leaf extracts were $5^{-5}, 9^{-5}, 19^{-3}, 28^{-3}$, and $38^{-3} \mathrm{mg} / \mathrm{plate}$. To each concentration of the extract, $0.5 \mathrm{~mL}$ of phosphate buffer $(0.2 \mathrm{M})$ and 0.1 $\mathrm{mL}$ of bacterial suspension were added, and then incubated at $37{ }^{\circ} \mathrm{C}$ for $30 \mathrm{~min}$. Next, $2 \mathrm{~mL}$ of top agar supplemented with histidine and biotin traits were added to the mixture. It was then slightly homogenized and plated on glucose minimal medium. After the top agar solidified, the plates were incubated at $37^{\circ} \mathrm{C}$ for $48 \mathrm{~h}$. and the revertant colonies were counted. The assay was performed in triplicate.

The mutagenic standards used to confirm the reversion of properties and specificity of each strain were sodium azide $(0.00125 \mathrm{mg} /$ plate $)$, 4-nitro-ophenylenediamine $(0.01 \mathrm{mg} /$ plate $)$, and mitomycin C $(0.0005 \mathrm{mg} /$ plate $)$. DMSO $(0,1 \mathrm{~mL} /$ plate $)$ was used as the negative control.

The concentration of the extract was expressed as units of mass/plate. The results were evaluated by the mutagenicity ratio (MR):

$\mathrm{MR}=$ number of revertants in test sample/ number of revertants in the negative control

The sample was considered to be mutagenic when there was a significant increase in the number of revertants and MR is greater than or equal to two, in at least one of the concentrations tested (Mortelmans and Zeiger 2000). 


\section{ASSESSMENT OF HEMOLYTIC ACTIVITY In vitro}

Blood $(5-10 \mathrm{~mL})$ was obtained by venipuncture from non-smoking and healthy volunteer with informed consent. The erythrocytes were separated by centrifugation at $1500 \mathrm{rpm}$ for $10 \mathrm{~min}$. After the plasma was removed, the erythrocytes were washed three times with phosphate buffered saline (PBS, $\mathrm{pH} 7.4$ ) and $1 \%$ erythrocyte suspension was prepared using the same buffer (adapted Khalil and El-Adawy 1994).

The hemolytic activity of ethanol bark extracts and ethanol leaf extracts were evaluated in vitro. Each tube received $1.1 \mathrm{~mL}$ of erythrocyte suspension and $0.4 \mathrm{ml}$ of the extracts $(0.05,0.1$, and $0.5 \mathrm{mg} / \mathrm{ml}$ ). PBS (solvent) and Quillaja saponina $(0.0025 \%)$ were the negative and positive control, respectively (Jandú et al. 2013). After $60 \mathrm{~min}$ of incubation at $37^{\circ} \mathrm{C}$, the cells were centrifuged, and the absorbance of the supernatant was measured using a spectrophotometer (540 nm), which indicates hemoglobin released.

Hemolytic activity was determined by the following formula:

Hemolytic activity $(\%)=(\mathrm{Ae}-\mathrm{An}) /(\mathrm{Ap}-$ $\mathrm{An}) \times 100$, where $\mathrm{Ae}=$ absorbance of the extract, $\mathrm{An}=$ absorbance of the negative control, and Ap $=$ absorbance of the positive control. The average value $(\mathrm{n}=3)$ was calculated.

\section{ACUTE TOXICITY TEST}

The acute toxicity of the extracts was investigated in 25 adult Wistar rats (65 days old, weighing approximately $250 \mathrm{~g}$ ) from the animal facility of the Universidade Federal da Grande Dourados (UFGD). The animals were kept at controlled conditions (12-hour light/12-hour dark cycle and temperature of $23{ }^{\circ} \mathrm{C}$ ), and received water and commercial feed ad libitum. The acute toxicity test was performed in accordance with the protocol of Organization for Economic Co-operation and Development (OECD 2015).
The animals were divided into five groups ( 5 animals/group) and treated with ethanol extracts (0-2000 mg/kg body weight) of the bark and leaves of $M$. urundeuva. The animals were fasted for 12 $\mathrm{h}$ before administration of the extracts and the treatments were administered as single oral dose (gavage). The animals were observed within the first hour and every $24 \mathrm{~h}$ for 14 days. Behavioral parameters were analyzed, such as irritability, twitching, righting reflex, tremors, convulsions, piloerection, breathing, and death. The body weight, amount of water, and food consumed by the group during the 14 days were also evaluated. On the $15^{\text {th }}$ day, all animals were weighed, anesthetized with ketamine $(25 \mathrm{mg} / \mathrm{kg})$ and xylazine $(10 \mathrm{mg} / \mathrm{kg})$, and euthanized.

The Ethics Committee of Animal Experimentation of UFGD approved the experimental procedures (Protocol 003/2012).

\section{Histological analysis}

All animals were autopsied at the end of the experiment to analyze the macroscopic characteristics of the liver, lung, and kidney. The organs were removed carefully and then individually weighed, fixed in $10 \%$ buffered formalin, and embedded in paraffin. Sections were obtained using a microtome. The sections were stained with hematoxylin-eosin and the slides were analyzed using an optical light microscope (40× magnification).

\section{STATISTICAL ANALYSIS}

Data analysis was performed using descriptive statistics, including Mann-Whitney and ANOVA tests. Differences were considered significant at $\mathrm{p}<$ 0.05 . The data were stored and analyzed using the Software BioEstat 5.0. 


\section{RESULTS AND DISCUSSION}

M. urundeuva of bark extracts showed best antifungal activity against $C$. albicans, major yeast associated with vulvovaginal candidiasis (Ilkit and Guzel 2011), however the leaves extract showed no activity for this species (Table I). This information confirms the popular use of the bark and no leaves.

Ethanol extracts bark showed the best antifungal activity compared to its fractions, Jandú et al. (2013) reported the bark methanol extract of M. urundeuva showed inhibitory effects against bacteria and fungi at concentrations 390-3190 mg/L. In this study, the ethanol bark extracts showed best activity $(0.004-0.512 \mathrm{mg} / \mathrm{mL})$, which was possible attributed the type of extraction employed, to place and collection period. Environmental variations can affect plant development and consequently influence the production of various chemical compounds, especially secondary metabolites, therefore, induce different response in biological tests.

The antifungal activity of M. urundeuva extracts can be attributed to the presence of flavonoids and tannins. Studies have confirmed the significance of flavonoids and tannins with the antifungal activity of M. urundeuva (Jandú et al. 2013, Siqueira et al. 2012, Araújo et al. 2008). In addition to their antifungal activity, it has been shown that these compounds possess antioxidant activity, antiinflammatory, and anticancer properties (Jandú et al. 2013, Siqueira et al. 2012, Araújo et al. 2008, Dourado and Ladeira 2008).

The ethanol extracts of the bark and leaves of $M$. urundeuva were analyzed by HPLC, which indicated the presence of substances such as flavonoids (flavanols and chalcones), phenols, and tannins. Sá et al. (2009) analyzed the chemical components of $M$. urundeuva ethanol extract using thin layer chromatography and noted the presence of flavonoids and tannins. Mota et al. (2015) evaluated the similarities between the phytochemical profiles of the leaves and bark of $M$. urundeuva and observed that the chromatographic profiles of the leaves and bark were similar however, the concentrations of some compounds differed, with higher concentration of functional compounds found in the bark compared to that of the leaves. Our results showed that the antimicrobial activity was greater in the bark extracts than that in the leaf extracts. Plants that have flavonoids and tannins with antifungal activity may also exhibit toxicity (Resende et al. 2012, Silva et al. 2014). Therefore, antimicrobial activity studies must be accompanied by toxicology studies.

All concentrations of ethanol bark extracts and ethanol leaf extracts influenced seed germination and root growth of $A$. серa, in a dose-response manner. Increasing concentration of the extracts resulted in a decrease in the number of seeds that germinated and size of the roots $(p<0.05)$ (Table II). These extracts reduced the mitotic activity of meristematic cells and did not show significant mutagenic activity to cells, as confirmed by the values of the CAI and MTI at the concentrations tested $(p>0.05)$. The results of the germination rate, root growth, and mitotic index indicated that the extracts reduced the number of cells in the plant tissue, suggesting antiproliferative activity. The reduction in the mitotic index of meristematic cells of A. cepa implies cytotoxic related cell death (Ping et al. 2012). In this study, concentration of $0.2 \mathrm{mg} /$ $\mathrm{mL}$ showed toxicity and significantly reduced the germination of seeds and growth of roots of $A$. cepa $(\mathrm{p}<0.05)$.

Several species of the Anacardiaceae family, in which M. urundeuva belongs to, are considered allelopathic (Donnelly et al. 2008), due to secondary metabolites derived from the metabolism of plants, and include flavonoids, tannins, steroids, and terpenoids and may be responsible for reducing or even inhibiting the germination of seeds and growth of roots (Li et al. 2010, Rodrigues et al. 2012). 


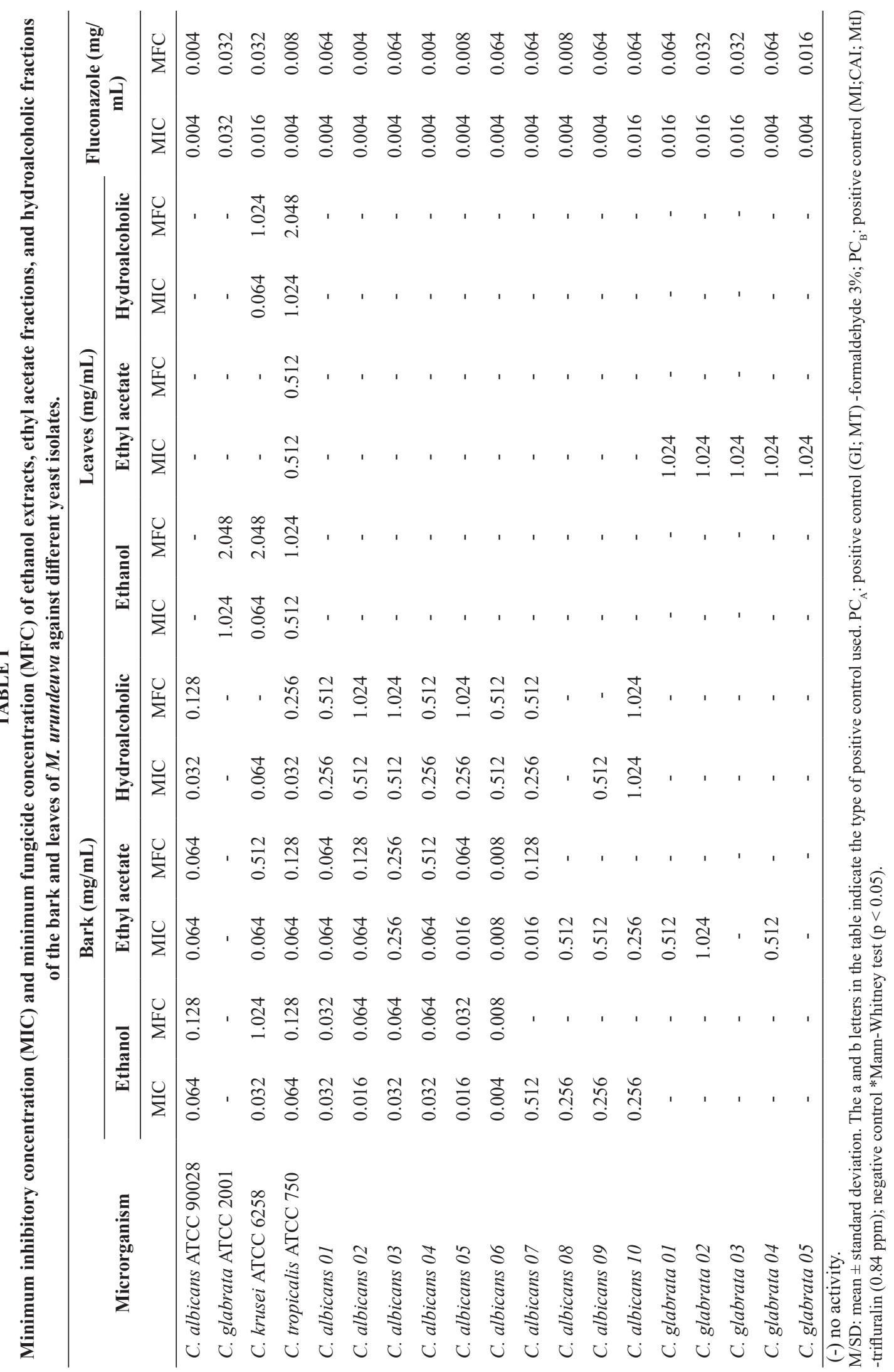


TABLE II

Germination index (GI) of seeds, medium-sized root (MS), mitotic index (MI), chromosomal alterations index (CAI), and mutagenicity index (MtI) for A. cepa after treatment with different concentrations of ethanol bark extracts and ethanol leaves extracts of M. urundeuva.

\begin{tabular}{|c|c|c|c|c|c|c|}
\hline Extracts & $\begin{array}{c}\text { Concentrations } \\
(\mathrm{mg} / \mathrm{mL})\end{array}$ & $\begin{array}{l}\text { GI (\%) } \\
(\mathrm{M} / \mathrm{SD}) \\
\end{array}$ & $\begin{array}{c}\text { MS } \\
(\mathrm{M} / \mathrm{SD}) \\
\end{array}$ & $\begin{array}{c}\text { MI } \\
(\mathbf{M} / \mathrm{SD}) \\
\end{array}$ & $\begin{array}{c}\text { CAI } \\
(\mathrm{M} / \mathrm{SD}) \\
\end{array}$ & $\begin{array}{c}\text { MtI } \\
(\mathrm{M} / \mathrm{SD})\end{array}$ \\
\hline \multirow{7}{*}{ Leaves } & Positive control & $0_{\mathrm{a}}$ & $0_{\mathrm{a}}$ & $1.12 \pm 0.97_{\mathrm{b}}{ }^{*}$ & $1.8 \pm 0.55_{\mathrm{b}}{ }^{*}$ & $1.98 \pm 0.31_{\mathrm{b}}^{*}$ \\
\hline & Negative control & $63 \pm 2.52$ & $1.95 \pm 0.10$ & $3.53 \pm 0.79$ & $0.01 \pm 0.02$ & $0.06 \pm 0.05$ \\
\hline & 0.2 & $48 \pm 2.00 *$ & $1.16 \pm 0.20 *$ & $3.34 \pm 1.20$ & $0.02 \pm 0.01$ & $0.09 \pm 0.07$ \\
\hline & 0.3 & $40 \pm 4.73 *$ & $0.80 \pm 0.34 *$ & $2.87 \pm 0.80^{*}$ & $0.02 \pm 0.01$ & $0.10 \pm 0.05$ \\
\hline & 0.4 & $47 \pm 1.53 *$ & $0.88 \pm 0.29 *$ & $2.79 \pm 1.41^{*}$ & $0.03 \pm 0.01$ & $0.10 \pm 0.12$ \\
\hline & 0.5 & $32 \pm 2.52 *$ & $0.58 \pm 0.23^{*}$ & $1.46 \pm 0.69^{*}$ & $0.02 \pm 0.02$ & $0.10 \pm 0.12$ \\
\hline & 1.0 & $17 \pm 3.06^{*}$ & $0.24 \pm 0.27 *$ & $0.83 \pm 0.47^{*}$ & $0.01 \pm 0.03$ & $0.10 \pm 0.10$ \\
\hline \multirow{7}{*}{ Bark } & Positive control & $0_{\mathrm{a}}$ & $0_{\mathrm{a}}$ & $0.91 \pm 0.88_{\mathrm{b}}^{*}$ & $1.8 \pm 0.55_{\mathrm{b}}^{*}$ & $1.68 \pm 0.31_{\mathrm{b}}^{*}$ \\
\hline & Negative control & $69 \pm 3.61$ & $1.97 \pm 0.12$ & $3.00 \pm 0.60$ & $0.01 \pm 0.02$ & $0.06 \pm 0.05$ \\
\hline & 0.2 & $42 \pm 1.53 *$ & $1.09 \pm 0.40 *$ & $1.78 \pm 0.32 *$ & $0.01 \pm 0.01$ & $0.02 \pm 0.05$ \\
\hline & 0.3 & $47 \pm 3.06^{*}$ & $1.14 \pm 0.31^{*}$ & $1.60 \pm 0.77 *$ & $0.01 \pm 0.02$ & $0.04 \pm 0.05$ \\
\hline & 0.4 & $56 \pm 1.53 *$ & $0.98 \pm 0.21 *$ & $1.83 \pm 0.49^{*}$ & $0.03 \pm 0.01$ & $0.04 \pm 0.05$ \\
\hline & 0.5 & $57 \pm 1.53 *$ & $0.91 \pm 0.18^{*}$ & $1.79 \pm 0.84^{*}$ & $0.01 \pm 0.01$ & $0.02 \pm 0.04$ \\
\hline & 1.0 & $45 \pm 2.65^{*}$ & $0.63 \pm 0.14^{*}$ & $1.12 \pm 0.13 *$ & $0.01 \pm 0.01$ & $0.02 \pm 0.04$ \\
\hline
\end{tabular}

Despite its cytotoxic activity, M. urundeuva extracts did not show mutagenic activity in the $A$. cepa test and AMES test did not show mutagenic activity of direct action at all concentrations tested in the four strains of $S$. Typhimurium (TA97a, TA98, TA100, and TA102), as shown by the mutagenicity ratio (less than 2) (Table III) (Maron and Ames 1983). The fact the extracts did not present direct mutagenicity to is relevant is to ensure the safe use of this plant, as it was not observed mutagenic changes in the A. cepa test and AMES test.

The extracts showed hemolytic activity of less than $25 \%$ at the concentrations tested, indicating that the bark and leaf extracts of M. urundeuva were not cytotoxic to erythrocytes. Other studies (Jandú et al. 2013, Carvalho and Oliveira 2012) evaluated the toxicity of methanol extract did not show hemolytic activity in erythrocytes.

In the acute toxicity test some symptoms such as lethargy, increased respiratory rate, and absence of movement they were soon observed after administration of the extracts. After $15 \mathrm{~min}$, movements were observed but high respiratory rate remained. On the first day, two rats (one from each group) had nasal bleeding and difficulty in breathing, and died on the following day. On gross examination, swollen abdomen was observed and after dissection, yellow structures and formation of internal voids were observed in the small intestine. Histopathological evaluation of the liver, lung, and kidney did not indicate abnormality in these organs.

In conclusion, the bark extracts of M. urundeuva showed best antifungal activity against $C$. albicans, major yeast associated with vulvovaginal candidiasis. Chemical analysis of the extracts confirmed the presence of flavonoids (flavanols and chalcones) and tannins. The ethanol extracts of the bark and leaves did not show mutagenic and genotoxic effects, but demonstrated cytotoxic and toxic properties. M. urundeuva bark extracts 
TABLE III

The number of revertant colonies and mutagenicity ratio of the different treatments of ethanol bark extract and ethanol leaves extract of $M$. urundeuva in $S$. Typhimurium strains (TA97a, TA98, TA100, and TA102).

\begin{tabular}{|c|c|c|c|c|c|c|c|c|c|}
\hline \multirow{2}{*}{ Extracts } & \multirow{2}{*}{$\begin{array}{l}\text { Treatment } \\
\text { (mg/plate) }\end{array}$} & \multicolumn{2}{|l|}{ TA97a } & \multicolumn{2}{|l|}{ TA98 } & \multicolumn{2}{|c|}{ TA100 } & \multicolumn{2}{|c|}{ TA102 } \\
\hline & & M/SD & MR & M/SD & MR & M/SD & MR & M/SD & MR \\
\hline \multirow{7}{*}{ Leaves } & $5^{-5}$ & $121.67 \pm 6.64$ & 1.26 & $14.67 \pm 2.08$ & 1.05 & $54.67 \pm 2.58$ & 1.12 & $214.67 \pm 4.69$ & 1.05 \\
\hline & $9^{-5}$ & $100.33 \pm 8.5$ & 1.04 & $14.67 \pm 3.54$ & 1.05 & $66.67 \pm 0.71$ & 1.37 & $329.33 \pm 4.73$ & 1.61 \\
\hline & $19^{-3}$ & $97.33 \pm 5.22$ & 1.01 & $12.67 \pm 2.52$ & 0.90 & $53.00 \pm 4.36$ & 1.09 & $285.67 \pm 5.73$ & 1.39 \\
\hline & $28^{-3}$ & $118.67 \pm 4.32$ & 1.23 & $13.00 \pm 4.24$ & 0.93 & $47.00 \pm 3.9$ & 0.97 & $255.00 \pm 6.19$ & 1.24 \\
\hline & $38^{-3}$ & $103.33 \pm 3.44$ & 1.07 & $13.67 \pm 2.12$ & 0.98 & $43.67 \pm 1.41$ & 0.90 & $273.00 \pm 4.95$ & 1.33 \\
\hline & $\begin{array}{l}\text { Negative } \\
\text { control }\end{array}$ & $96.33 \pm 2.44$ & 1 & $14.00 \pm 1.3$ & 1 & $48.67 \pm 2.2$ & 1 & $205.00 \pm 10.45$ & 1 \\
\hline & $\begin{array}{c}\text { Positive } \\
\text { control }\end{array}$ & $729.00 \pm 5.5 *$ & 7.57 & $569.33 \pm 8.85^{*}$ & 40.67 & $512.33 \pm 4.3^{*}$ & 10.53 & $1143.00 \pm 25.67 *$ & 5.58 \\
\hline \multirow{7}{*}{ Bark } & $5^{-5}$ & $154.67 \pm 6.29$ & 1.61 & $12.67 \pm 1.15$ & 0.90 & $69.00 \pm 8.89$ & 1.42 & $260.00 \pm 2.83$ & 1.27 \\
\hline & $9^{-5}$ & $152.67 \pm 2.03$ & 1.58 & $14.00 \pm 3.36$ & 1.00 & $60.67 \pm 4.85$ & 1.25 & $154.67 \pm 6.71$ & 0.75 \\
\hline & $19^{-3}$ & $93.33 \pm 9.29$ & 0.97 & $15.00 \pm 2.65$ & 1.07 & $59.00 \pm 7.78$ & 1.21 & $165.67 \pm 4.33$ & 0.81 \\
\hline & $28^{-3}$ & $110.00 \pm 8.42$ & 1.14 & $14.33 \pm 2.12$ & 1.02 & $65.67 \pm 8.49$ & 1.35 & $267.67 \pm 9.19$ & 1.31 \\
\hline & $38^{-3}$ & $97.67 \pm 8.99$ & 1.01 & $15.33 \pm 4.24$ & 1.10 & $78.00 \pm 9.09$ & 1.60 & $192.67 \pm 3.21$ & 0.94 \\
\hline & $\begin{array}{l}\text { Negative } \\
\text { control }\end{array}$ & $96.33 \pm 2.44$ & 1 & $14.00 \pm 1.3$ & 1 & $48.67 \pm 2.2$ & 1 & $205.00 \pm 10.45$ & 1 \\
\hline & $\begin{array}{l}\text { Positive } \\
\text { control }\end{array}$ & $729.00 \pm 5.5^{*}$ & 7.57 & $569.33 \pm 8.85^{*}$ & 40.67 & $512.33 \pm 4.3 *$ & 10.53 & $1143.00 \pm 25.67 *$ & 5.58 \\
\hline
\end{tabular}

showed potential for the treatment of vaginal infections caused Candida species, however, it is more suitable as a topical formulation.

\section{ACKNOWLEDGMENTS}

The authors are grateful to Fundação de Apoio ao Desenvolvimento do Ensino, Ciência e Tecnologia do Estado de Mato Grosso do Sul (FUNDECT) for the financial support and the Coordenação de Aperfeiçoamento de Pessoal de Nível Superior (CAPES) for funding a scholarship for postgraduate studies. All authors declare that they have no conflict of interest.

\section{REFERENCES}

ÁLVARES CA, SVIDZINSKI TIE AND CONSOLARO MEL. 2007. Candidíase vulvovaginal: fatores predisponentes do hospedeiro e virulência das leveduras. J Bras Patol Med Lab 5: 319-327.
ARAÚJO TAS, ALENCAR NL, AMORIM ELC AND ALBUQUERQUE UP. 2008. A new approach to study medicinal plants with tannins and flavonoids contents from the local knowledge. J Ethnopharmacol 120: 72-80.

BAGIU RV, VLAICU B AND BUTNARIU M. 2012. Chemical composition and in vitro antifungal activity screening of the Allium ursinum L. (Liliaceae). Int J Mol Sc 13: 14261436.

BRASIL. 2015. Agência Nacional de Vigilância Sanitária. Consolidado de normas da COFID (Versão V). Available at http://portal.anvisa.gov.br/wps/wcm/ connect/f8183a004707cee086319741cdd33a01/ Consolidado+COFID+V.pdf?MOD=AJPERES. Accessed April 08, 2015.

CARVALHO MS AND OLIVEIRA DA. 2012. Estudo da atividade citotóxica de Myracrodruon urundeuva FR. Allemão. Rev Eletr Biol 5: 1-7.

CLSI - CLINICAL AND LABORATORY STANDARDS INSTITUTE. 2008. M27-A3 reference method for broth dilution antifungal susceptibility testing of yeasts; approved standard, third edition. Clinical and Laboratory Standards Institute, Wayne: 2008.

DONNELLY MJ, GREEN DM AND WALTERS LJ. 2008. Allelopathic effects of fruits of the Brazilian pepper 
Schinus terebinthifolius on growth, leaf production and biomass of seedlings of the red mangrove Rhizophora mangle and the black mangrove Avicennia germinans. J Exp Mar Bio Ecol 357: 149-156.

DOURADO RS AND LADEIRA AM. 2008. Identification of flavonoids in Hypericum cordatum (Vell.) N. Robson (Clusiaceae). Braz J Bot 31: 611-620.

EREN Y AND ÖZATA A. 2014. Determination of mutagenic and cytotoxic effects of Limonium globuliferum aqueous extracts by Allium, Ames, and MTT tests. Rev Bras Farmacog 24: 51-59.

FERNANDES TCC, MAZZEO DEC AND MARINMORALES MA. 2007. Mechanism of micronuclei formation in polyploidizated cells of Allium cepa exposed to trifluralin herbicide. Pestic Biochem Phys 88: 252-259.

FISKESJÖ G. 1994. Allium test II: Assesmente of chemical's genotoxic potential by recording aberrations in chromosomes and cell divisions in root tips of Allium cepa L. Environ Toxic Water 9: 235-241.

GEHRKE ITS, NETO AT, PEDROSO M, MOSTARDEIRO CP, DA CRUZ IBM, SILVA UF, ILHA V, DALCOL II AND MOREL AF. 2013. Antimicrobial activity of Schinus lentiscifolius (Anacardiaceae). J Ethnopharmacol 148: 486-491.

ILKIT M AND GUZEL AB. 2011. The epidemiology, pathogenesis, and diagnosis of vulvovaginal candidosis: a mycological perspective. Crit Rev Microbiol 37: 250-261.

JANDÚ JJB, CLÁUDIO L, CAETANO ADP, SOUZA RMD, ALBERTO C, BRESSAN RC, FIGUEIREDO QD, ARAÚJO JMD, TEREZA M AND VANUSA M. 2013. Myracrodruon urundeuva bark: an antimicrobial, antioxidant and non-cytotoxic agent. J Med Plants Res 7: 413-418.

KHALIL AH AND EL-ADAWY TA. 1994. Isolation, identification and toxicity of saponin from different legumes. Food Chem 50: 197-201.

LI ZH, WANG Q, RUAN X, PAN CD AND JIANG DA. 2010. Phenolics and plant allelopathy. Molecules 15: 8933-8952.

LOPES JM. 2011. O conhecimento tradicional e o uso de plantas medicinais por mulheres indígenas da aldeia Jaguapiru. Trabalho de Conclusão de Curso. Curso de Licenciatura Intercultural Indígena. UFGD, Dourados, MS: 2011. (Unpublished).

LORENZI H AND MATOS FJA. Plantas medicinais no Brasil: nativas e exóticas. Plantarum 2008: $2^{\mathrm{a}}$ ed., Nova Odessa.

MARON DM AND AMES BN. 1983. Revised methods for the Salmonella mutagenicity test. Mutat Res 113: 173-215.

MORTELMANS K AND ZEIGER E. 2000. The Ames Salmonella/microsome mutagenicity assay. Mutat ResFund Mol M 455: 29-60.
MOTA BCF, ROYO VDA, FONSECA JMS, SANTOS AD, JÚNIOR AFDM, MENEZES EV, ESPERANDIM VR AND LAURENTIZ RDS. 2015. Comparative studies between the chemical constituents and biological properties of the extracts from the leaves and barks of Myracrodruon urundeuva Fr. All. J Med Plants Res 9: 159-168.

OECD - ORGANIZATION FOR ECONOMIC COOPERATION AND DEVELOPMENT. 2015. Guidelines for the testing of chemicals: Acute Oral Toxicity - Fixed Dose Procedure. OECD, Guideline 2001: 420, Paris. Available at http://www.oecd ilibrary. org/environment/test-no-420-acute-oral-toxicity-fixeddose-procedure_9789264070943-en. Accessed January 20, 2015.

PING KY, DARAH I, YUSUF UK, YENG C AND SASIDHARAN S. 2012. Genotoxicity of Euphorbia hirta: an Allium cepa assay. Molecules 17: 7782-7791.

RESENDE FA, VILEGAS W, DOS SANTOS LC AND VARANDA EA. 2012. Mutagenicity of flavonoids assayed by bacterial reverse mutation (Ames) test. Molecules 17: 5255-5268.

RODRIGUES AC, ARTIOLI FA, POLO M, BARBOSA LCA AND BEIJO LA. 2012. Efeito alelopático de folhas de bamburral [ Hyptis suaveolens ( L .) Poit .] sobre a germinação de sementes de sorgo (Sorghum vulgare Pers .), rabanete (Raphanus sativus L .) e alface (Lactuca sativa L .). Rev Bras Plant Med 14: 487-493.

SÁ RA ET AL. 2009. Antioxidant, fusarium growth inhibition and nasutitermes corniger repellent activities of secondary metabolites from Myracrodruon urundeuva heartwood. Int Biodeterior Biodegradation 63: 470-477.

SILVA CA, SILVA CR, VÉRAS JH, CHEN-CHEN L, FERRI PH AND SANTOS SDC. 2014. Genotoxicity and cytotoxicity evaluation of oenothein $\mathrm{B}$ and its protective effect against mitomycin $\mathrm{C}$-induced mutagenic action. Mutat Res Genet Toxicol Environ Mutagen 767: 8-12.

SIQUEIRA CFDQ, CABRAL DLV, PEIXOTO SOBRINHO TJDS, AMORIM ELC, MELO JG, ARAÚJO TADS AND ALBUQUERQUE UP. 2012. Levels of tannins and flavonoids in medicinal plants: evaluating bioprospecting strategies. J Evid Based Complementary Altern Med: 434782

WHO - WORLD HEALTH ORGANIZATION. 2015. Operational guidance: Information needed to support clinical trials of herbal products. TDR/GEN/ Guidance/05.1, Geneva 2005. Available at http:// www. who.int/tdr/publications/documents/operational-guidanceeng.pdf. Accessed April 01, 2015. 